\title{
Asymmetric synthesis of azidotetrahydropyranols via Sharpless epoxidation
}

\author{
Quyen Ong ${ }^{\mathrm{a}}$, Sheetal Handa ${ }^{\mathrm{a}}$, Antonio Mete ${ }^{\mathrm{b}}$, Alison M. Hill ${ }^{\mathrm{a}}$, and Keith Jones ${ }^{\mathrm{a} *}$ \\ ${ }^{a}$ Department of Chemistry, King's College London, Strand, London WC2R 2LS. U. K. \\ ${ }^{b}$ AstraZeneca R\&D, Charnwood, Bakewell Road, Loughborough LE11 5RH. U. K. \\ E-mail: keith.jones@kingston.ac.uk
}

\section{Dedicated to Dr Douglas Lloyd on the occasion of his $80^{\text {th }}$ birthday}

\begin{abstract}
An approach to the synthesis of enantiomerically pure azidotetrahydropyranols 4 involving stereospecific reduction of propargylic alcohol 7 followed by Sharpless epoxidation of the resultant alllyic alcohols $\mathbf{8}$ and $\mathbf{1 2}$ is presented. Epoxide $\mathbf{1 0}$ undergoes ring opening with trimethyl orthoformate whereas epoxide 15 undergoes the expected ring opening with azide.
\end{abstract}

Keywords: Asymmetric synthesis, azidotetrahydropyranols, Sharpless epoxidation

\section{Introduction}

The use of enzymes in the synthesis of complex molecules has received much attention over the last 20 years. In particular, the employment of various aldolase enzymes in the synthesis of natural and non-natural carbohydrates has been demonstrated by a number of groups. ${ }^{1}$ Our own contribution to this area (Scheme 1) involved a chemoenzymatic synthesis of $\beta$-homonojirimycin 1 via the rabbit muscle aldolase (RAMA) catalysed reaction of hemiacetal 2 with dihydroxyacetone phosphate to give azidoheptulose 3 followed by catalytic hydrogenation to give $\mathbf{1 .}^{2}$

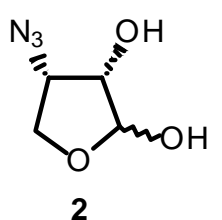

2

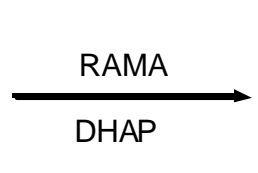

DHAP<smiles>[N]C(CO)[C@H](O)[C@H](O)[C@H](O)C(=O)CO</smiles>

3

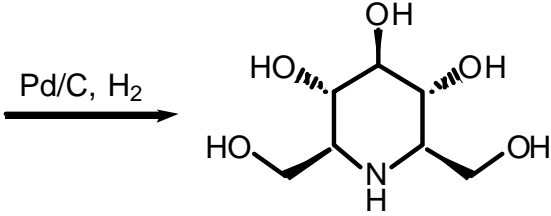

1

\section{Scheme 1}


The hemiacetal 2 was prepared as a single enantiomer by Sharpless epoxidation and during this work it was found that hemiacetals such as $\mathbf{2}$ are better substrates for RAMA than the corresponding open chain hydroxy-protected aldehydes. These results stand in contrast to the results obtained by Bednarski who investigated the use of natural hemiacetals as substrates for RAMA. They found that D-erythrose, D-ribose, D-arabinose and D-glucose are all very poor substrates for RAMA reacting at less than $1 \%$ of the rate of propanal. ${ }^{3}$ In order to further test our approach and to explore the rate enhamcement we had found with hemiacetals, we decided to prepare homologues of $\mathbf{2}$ based on the 4-azido-3-hydroxytetrahydropyranol system 4 . If successful as substrates for RAMA, a new series of aza-sugar analogues could be prepared.

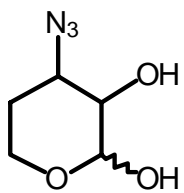

4

\section{Figure 1}

\section{Result and Discussion}

Our approach to the target molecules 4 was based on our previous synthesis of hemiacetals 2 . This required a stereospecific synthesis of both the cis- and trans-5-protected pent-2-ene-1,5diols (Scheme 2). Protection of 3-butynol 5 with $t$-butyldiphenylsilyl chloride following the procedure of $\mathrm{Wipf}^{4}$ gave silyl ether 6 in $92 \%$ yield. Earlier studies using the $t$-butyldimethylsilyl protecting group had indicated that a more stable silyl ether was required to survive the subsequent synthetic steps intact. Generation of the acetylenic anion with $n$-butyllithium in THF at $-23{ }^{\circ} \mathrm{C}$ followed by addition of dry paraformaldehyde ${ }^{5}$ gave the monoprotected diol 7 in $86 \%$ yield. Reduction to the cis-alkene was first attempted using the conditions of Takano ${ }^{6}$ involving Lindlar's catalyst and an excess of quinoline led to a 2:1 mixture of the cis- and trans-alkenes. A non-stereospecific reduction of a propargylsilane has been reported previously ${ }^{7}$ using a similar catalyst system. After a number of experiments, it was found that replacing the quinoline with pyridine gave the cis-alkene 8 in $96 \%$ yield as a single stereoisomer. The coupling constant for the alkene protons $(10 \mathrm{~Hz})$ confirmed the stereochemistry.

Sharpless epoxidation ${ }^{8}$ of the cis-allylic alcohol 8 was carried out using (-)-diethyl tartrate under the usual conditions to give the epoxide 9 in excellent chemical yield. The optical purity of 9 was assessed by formation of the Mosher's ester (100\% yield) and examination of the ${ }^{19} \mathrm{~F} \mathrm{nmr}$ spectrum. The major diastereoisomer showed a resonance at $\delta_{\mathrm{F}}-72.16$ and the minor diastereoisomer a resonance at $\delta_{\mathrm{F}}-72.22$. The relative integration was 88.5:11.5 indicating an 
enantiomeric excess of 77\%. The absolute stereochemistry is assigned based on well-established precedent from the work of Sharpless. ${ }^{9}$ Oxidation of the epoxyalcohol $\mathbf{9}$ to the aldehyde $\mathbf{1 0}$ was best carried out using tetrapropylammonium perruthenate (TPAP) ${ }^{10}$ with $N$-methylmorpholine$\mathrm{N}$-oxide as the stoichiometric oxidant to give the rather unstable aldehyde $\mathbf{1 0}$ in $80 \%$ yield. The next step in our synthesis involved the protection of the aldehyde as its dimethyl acetal in order to allow opening of the epoxide by azide at the 3-position, remote from the acetal. ${ }^{2}$ Treatment of epoxyaldehyde $\mathbf{1 0}$ with trimethylorthoformate in the presence of Amberlyst resin did not give the desired epoxyacetal but instead proceeded with ring opening of the epoxide by the methanol produced in the reaction to give the ether acetal 11 (scheme 3) in 86\% yield. The assignment of this structure to the product was based on the appearance of an extra singlet at $\delta 3.39$ in the ${ }^{1} \mathrm{H}$ $\mathrm{nmr}$ and a broad singlet at $\delta 2.4$ corresponding to an $\mathrm{OH}$ proton. The FAB mass spectrum also showed a strong peak at $\mathrm{m} / \mathrm{z} 455$ corresponding to $(\mathrm{M}+\mathrm{Na})^{+}$and the infra-red spectrum confirmed the presence of an $\mathrm{O}-\mathrm{H}$ group. Furthermore treatment with azide under conditions for opening the epoxide gave only starting material as would be expected for ether 11. Both the regio- and stereochemistry assigned to $\mathbf{1 1}$ is based on the expected site of reaction and the known mode of epoxide ring opening. We cannot exclude the possibility that the methanol ring opens the epoxide at C-2 although this seems unlikely on electronic grounds. ${ }^{2}$

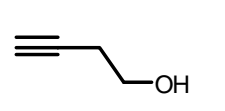

5
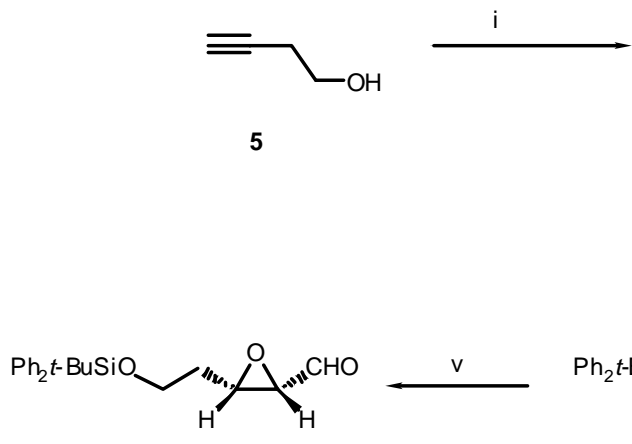

10

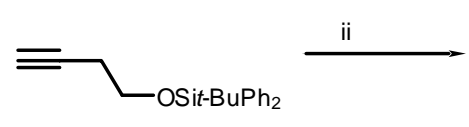

6

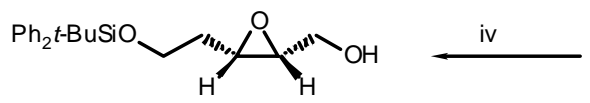

9

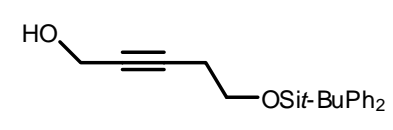

7
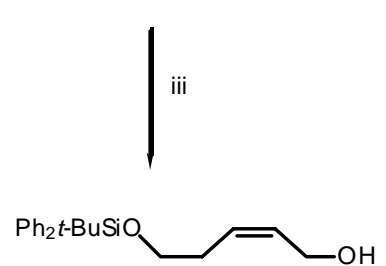

8

Scheme 2. Reagents: (i). TBDPS-Cl, imidazole, DMAP, DMF, 92\%; (ii). $n$-BuLi, THF, $-23{ }^{\circ} \mathrm{C}$, then paraformaldehyde, $86 \%$; (iii). $\mathrm{H}_{2}, \mathrm{Pd} / \mathrm{BaSO}_{4}$, pyridine, $96 \%$; (iv). (-)-diethyl tartarte, $\mathrm{Ti}(\mathrm{OiPr})_{4}, t \mathrm{BuOOH}$, mol. sieves, $\mathrm{CH}_{2} \mathrm{Cl}_{2}, 88 \%$, 77\% ee; (v). TPAP, NMMO, mol. sieves, $\mathrm{CH}_{2} \mathrm{Cl}_{2}, 80 \%$.

Faced with this unexpected result, we turned our attention to the trans-allylic alcohol. Reaction of propargyl alcohol 7 with lithium aluminium hydride gave the trans-allylic alcohol 12 in $76 \%$ yield. The two alkene protons overlap in the ${ }^{1} \mathrm{H} \mathrm{nmr}$ and hence it was impossible to ascertain the stereochemistry from the coupling constants. Nevertheless, the spectral data were entirely consistent with the gross structure and it was clear from the data for cis-alcohol $\mathbf{8}$ that this was a stereoisomer. 


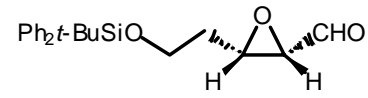

10

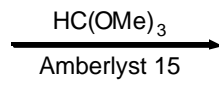

Amberlyst 15

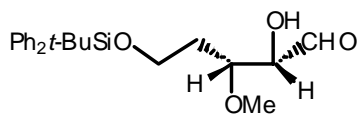

11

Scheme 3.
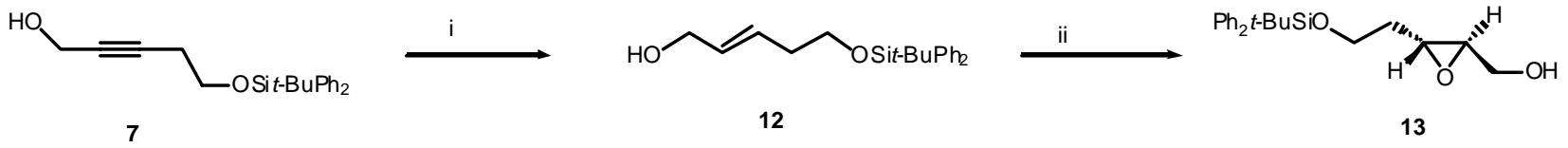

13
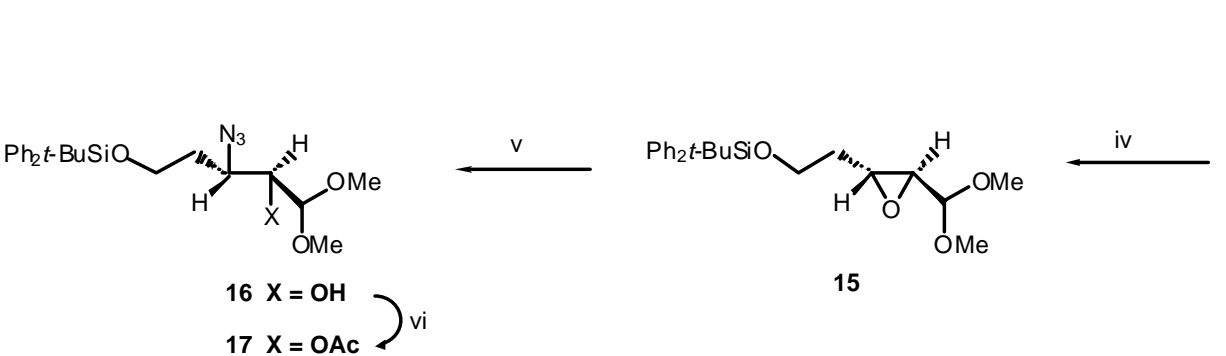

15

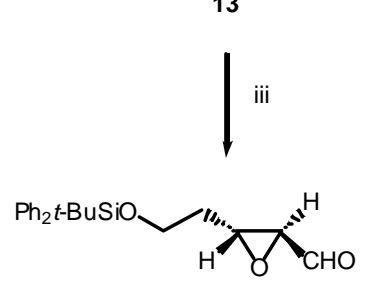

14

Scheme 4. Reagents: (i). $\mathrm{LiAlH}_{4}$, THF, $45^{\circ} \mathrm{C}, 76 \%$; (ii). (-)-diethyl tartarte, $\mathrm{Ti}(\mathrm{OiPr})_{4}, t \mathrm{BuOOH}$, mol. sieves, $\mathrm{CH}_{2} \mathrm{Cl}_{2}, 86 \%$, 95\% ee; (iii). TPAP, $\mathrm{NMMO}$, mol. sieves, $\mathrm{CH}_{2} \mathrm{Cl}_{2}, 80 \%$; (iv). $\mathrm{HC}(\mathrm{OMe})_{3}$, Amberlyst- $15,0{ }^{\circ} \mathrm{C}, 85 \%$; (v). $\mathrm{NaN}_{3}, \mathrm{MeOH}: \mathrm{H}_{2} \mathrm{O}$ (8:1), 74\%; (vi). Pyridine, acetic anhydride, $95 \%$.

Sharpless epoxidation of trans-allylic alcohol 12 using (-)diethyl tartrate gave the epoxide 13 in $86 \%$ yield. The enantiomeric purity of $\mathbf{1 3}$ was again assessed by conversion into its Mosher's ester derivative. The ${ }^{19} \mathrm{~F} n m r$ of the crude derivative showed two peaks at $\delta_{\mathrm{F}}-72.21$ and -72.01 integrating in a ratio of 97.5:2.5 indicating an enantiomeric excess of 95\%. In order to confirm this result, the racemic epoxide was prepared using $m$-chloroperoxybenzoic acid and its Mosher's derivative synthesised. The spectral data for this compound confirmed our assignment of the two resonances in the ${ }^{19} \mathrm{~F} \mathrm{nmr}$. The stereochemistry assigned to $\mathbf{1 3}$ is based on literature precedent again. Oxidation to the aldehyde 14 proceeded smoothly using TPAP and NMMO in $80 \%$ and this somewhat unstable compound was reacted with trimethyl orthoformate to give the dimethyl acetal 15 in $85 \%$ yield. In the case of this diastereoisomeric epoxide, no ring opening of the epoxide was observed in contrast to the outcome of the same reaction on epoxyaldehyde 10. The epoxide was then ring opened using sodium azide in methanol/water to give azido alcohol 16 in 74\% yield. Confirmation of the regiochemistry of ring opening was obtained by acetylation of the hydroxy group in $\mathbf{1 6}$ to give acetate 17. The ${ }^{1} \mathrm{H} \mathrm{nmr}$ of $\mathbf{1 7}$ showed that the original multiplet assigned to the C-2 proton at $\delta 3.74-3.77$ had moved downfield to $\delta 5.12$ and had become a dd. Meanwhile the ddd assigned to the C-3 proton moved from $\delta 3.86$ (in 16) to $\delta 3.94$ (in 17). This result agrees with the previous studies on the butane diol system. ${ }^{2}$ The final steps in 
the preparation of 4 simply involved hydrolysis of the acetal and removal of the silyl protecting group (scheme 5). This gave the $[3 S, 4 S]$-isomer of $\mathbf{4}$ as a mixture of anomers. Unfortunately, this anomeric mixture led to a very complex ${ }^{1} \mathrm{H} \mathrm{nmr}$ with only the anomeric proton clearly visible as a doublet $(J 5 \mathrm{~Hz})$ at $\delta 5.00$ for the major anomer and a broad singlet at $\delta 4.79$ for the minor anomer. The ratio of the two anomers was 2.9:1. The ${ }^{13} \mathrm{C} \mathrm{nmr}$ was more useful for characterisation but the hemiacetals were characterised by conversion into the methyl acetals 18. Although the ${ }^{1} \mathrm{H} \mathrm{nmr}$ of the mixture of methyl acetals was considerably clearer it was not possible to derive the conformation of the tetrahydropyran ring owing to overlapping signals. However, for both anomers, the C-2 proton appeared as a doublet with $J 3.6$ and $2.9 \mathrm{~Hz}$ for major and minor anomer respectively indicating the C-3 hydroxy group is probably axial in both isomers.

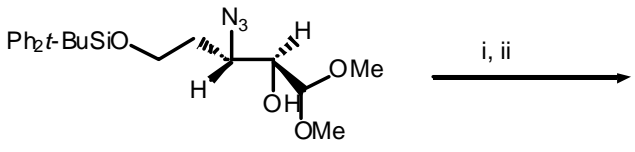

16

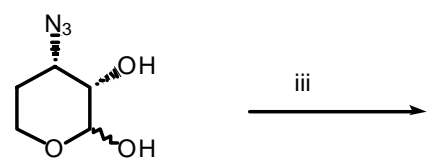

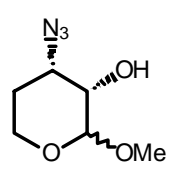

18

Scheme 5. Reagents: (i). $1 \%$ aqueous $\mathrm{CF}_{3} \mathrm{COOH}, \mathrm{CHCl}_{3}$; (ii). TBAF, THF, 55\%; (iii). $\mathrm{HC}(\mathrm{OMe})_{3}, \mathrm{TsOH}, 70 \%$.

In summary, we have been able to prepare one of the diastereoisomeric azido tetrahydropyranols for use in the RAMA-catalysed reaction with dihydroxyacetone phosphate but this route appears not to be general as was the case for the butane diol series.

\section{Acknowledgements}

We are grateful to Astra Charnwood for a CASE award (QO).

\section{Experimental Section}

1-(tert-Butyldiphenylsilyloxy)-3-butyn-1-ol (6) ${ }^{4}$. To a cooled $\left(0{ }^{\circ} \mathrm{C}\right)$ and stirring solution of 3butyn-1-ol (2.10 g, $30.0 \mathrm{mmol})$ in dry dichloromethane $(60 \mathrm{ml})$ was added, tertbutyldiphenylsilyloxy chloride $(8.52 \mathrm{~g}, 7.95 \mathrm{ml}, 31.0 \mathrm{mmol})$ over a 10 minute period. Imidazole ( $2.86 \mathrm{~g}, 42.0 \mathrm{mmol})$ was then added in one portion followed by 4-dimethylaminopyridine $(0.37 \mathrm{~g}$, $3.00 \mathrm{mmol}$ ) and the resultant mixture stirred at RT overnight. The white precipitate produced was filtered through a sintered funnel and washed with cold dichloromethane $(50 \mathrm{ml})$. The combined filtrates was then washed with a $1 \mathrm{M}$ aqueous $\mathrm{HCl}$ solution $(50 \mathrm{ml})$ and water $(100 \mathrm{ml})$ successively. The organic layer dried and the solvent removed in vacuo and the residue purified 
Kugelrohr distillation to give the protected acetylenic alcohol 6 as a colourless oil $(8.51 \mathrm{~g}, 92 \%$, bp. $\left.150-152^{\circ} \mathrm{C} / 1 \mathrm{~mm} \mathrm{Hg}\right) . \delta_{\mathrm{H}} 1.05\left(9 \mathrm{H}, \mathrm{s}, \mathrm{C}\left(\mathrm{CH}_{3}\right)_{3}\right), 1.93(1 \mathrm{H}, \mathrm{t}, J 2.6,4-H), 2.44(2 \mathrm{H}, \mathrm{td}, J 7.1$ and 2.6, 2- $\left.\mathrm{H}_{2}\right), 3.78\left(2 \mathrm{H}, \mathrm{t}, J\right.$ 7.1, 1- $\left.\mathrm{H}_{2}\right), 7.35-7.44(6 \mathrm{H}, \mathrm{m}, \mathrm{Ph}-\mathrm{H}), 7.66-7.69(4 \mathrm{H}, \mathrm{m}, \mathrm{Ph}-\mathrm{H}) ; \delta_{\mathrm{C}}$ $19.3\left(\mathrm{C}\left(\mathrm{CH}_{3}\right)_{3}\right), 22.7(\mathrm{C}-2), 26.9\left(\mathrm{C}\left(\mathrm{CH}_{3}\right)_{3}\right), 62.4(\mathrm{C}-1), 69.4(\mathrm{C}-4), 81.6(\mathrm{C}-3), 127.8,129.8$, 133.6 and $135.7(\mathrm{Ph}) ; v_{\max } / \mathrm{cm}^{-1} 3307$ (m, C三C-H str.), 3070 (m, Ph-H str.), 2961 and 2931 (s, sat. C-H str.), 1112 (s, C-O str.); m/z (FAB) 361 (100\%, M+Na+); (CI, NH 3 ) $326(100 \%$, $\left.\left[\mathrm{M}+\mathrm{NH}_{4}\right]^{+}\right), 309\left(10, \mathrm{M}+\mathrm{H}^{+}\right)$; (Found: $(\mathrm{FAB})[\mathrm{M}+\mathrm{H}]^{+}=308.1594, \mathrm{C}_{20} \mathrm{H}_{24} \mathrm{OSi}$ requires $[\mathrm{MH}]^{+}$ 308.1596), (Found: $\left(\mathrm{CI}, \mathrm{NH}_{3}\right)\left[\mathrm{M}+\mathrm{NH}_{4}\right]^{+}=326.1925, \mathrm{C}_{20} \mathrm{H}_{24} \mathrm{OSi}$ requires $\left[\mathrm{M}+\mathrm{NH}_{4}\right]^{+} 326.1940$ ). 5-(tert-Butyldiphenylsilyloxy)-2-pentyn-1-ol (7). To a cooled $\left(-23{ }^{\circ} \mathrm{C}\right)$ and stirred solution of 1(tert-butyldiphenylsilyloxy)-3-butyn-1-ol 6 (6.17 g, $20.0 \mathrm{mmol})$ in dry THF (100 ml), was added dropwise, $n$-butyllithium $(8.8 \mathrm{ml}, 22.0 \mathrm{mmol}$ of a $2.5 \mathrm{M}$ soln in hexane) whilst maintaining the temperature at $-23{ }^{\circ} \mathrm{C}$. The resultant mixture was stirred at $0{ }^{\circ} \mathrm{C}$ for $2 \mathrm{hrs}$, cooled $\left(-23{ }^{\circ} \mathrm{C}\right)$ and dry paraformaldehyde $(1.00 \mathrm{~g}, 30.0 \mathrm{mmol})$ was added in five portions. The mixture was stirred at $-23{ }^{\circ} \mathrm{C}$ for $1 \mathrm{hr}$, then warmed to $0{ }^{\circ} \mathrm{C}$ over several hours and stirred at RT overnight. The reaction mixture was then poured into a large excess of ice water $(200 \mathrm{ml})$ and the organic layer separated. The aqueous phase was extracted with ethyl acetate $(3 \times 200 \mathrm{ml})$ and the combined organic extracts dried, filtered and the solvent removed in vacuo. The product was purified by flash chromatography (20\% EtOAc in hexane to $30 \%$ EtOAc in hexane) to give the protected propargylic alcohol 7 as a colourless oil $(5.84 \mathrm{~g}, 86 \%) . \mathrm{R}_{\mathrm{f}}\left(30 \%\right.$ EtOAc in hexane) $0.60, \delta_{\mathrm{H}} 1.05$ $\left(9 \mathrm{H}, \mathrm{s}, \mathrm{C}\left(\mathrm{CH}_{3}\right)_{3}\right), 1.51(1 \mathrm{H}$, br.s, $\mathrm{OH}), 2.47\left(2 \mathrm{H}, \mathrm{td}, \mathrm{J} 7.0\right.$ and 2.2, 4- $\left.\mathrm{H}_{2}\right), 3.77\left(2 \mathrm{H}, \mathrm{t}, \mathrm{J}\right.$ 7.0, 5- $\left.\mathrm{H}_{2}\right)$,

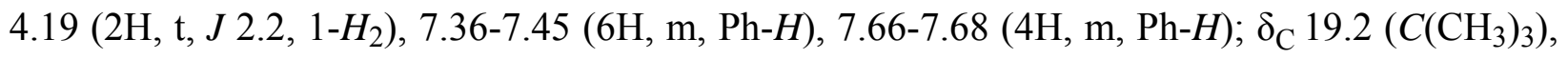
22.9 (C-4), $26.8\left(\mathrm{C}\left(\mathrm{CH}_{3}\right)_{3}\right), 51.3$ (C-5), 62.4 (C-1), 79.5 (C-3), 83.4 (C-2), 127.7, 129.7, 135.6 and $135.6(\mathrm{Ph}) ; v_{\max } / \mathrm{cm}^{-1} 3300-3500(\mathrm{~m}$, br., $\mathrm{OH}), 3070$ (m, Ph-H str.), 2958 and 2931 (s, sat. CH str.), 1112 (s, C-O str.); m/z (FAB) $362\left(29 \%,[\mathrm{M}+\mathrm{H}+\mathrm{Na}]^{+}\right), 361\left(100, \mathrm{M}+\mathrm{Na}^{+}\right)$; (Found: $(\mathrm{FAB})[\mathrm{M}+\mathrm{Na}]^{+}=361.1613, \mathrm{C}_{21} \mathrm{H}_{26} \mathrm{O}_{2}$ Si requires $\left.[\mathrm{M}+\mathrm{Na}]^{+} 361.1600\right)$.

(Z)-5-(tert-Butyldiphenylsilyloxy)pent-2-en-1-ol (8). A solution of the propargylic alcohol 7 $(6.77 \mathrm{~g}, 20.0 \mathrm{mmol})$ in pyridine $(125 \mathrm{ml})$ was degassed with argon $(30 \mathrm{~min})$, then $5 \%$ palladium on barium sulfate $(400 \mathrm{mg}$ ) was added and the mixture hydrogenated overnight using a balloon. The mixture was filtered through celite, the solvent removed in vacuo and the residue purified by flash chromatography (40\% EtOAc in hexane to 50\% EtOAc in hexane) to give the cis-allylic alcohol 8 as a colourless oil $(6.54 \mathrm{~g}, 96 \%) . \mathrm{R}_{\mathrm{f}}\left(50 \%\right.$ EtOAc in hexane) $0.37, \delta_{\mathrm{H}} 1.04(9 \mathrm{H}, \mathrm{s}$, $\left.\mathrm{C}\left(\mathrm{CH}_{3}\right)_{3}\right), 1.74(1 \mathrm{H}$, br.s, $\mathrm{OH}), 2.24\left(2 \mathrm{H}, \mathrm{td}, J 7.5\right.$ and $\left.1.2,4-\mathrm{H}_{2}\right), 3.53\left(2 \mathrm{H}, \mathrm{t}, \mathrm{J} 7.5,5-\mathrm{H}_{2}\right), 4.12$ $\left(2 \mathrm{H}, \mathrm{dd}, J 6.7\right.$ and 1.2, 1- $\left.\mathrm{H}_{2}\right), 5.57(1 \mathrm{H}$, dddd, $J$ 9.8, 7.5, 2.5 and 1.2, 3-H), $5.68(1 \mathrm{H}, \mathrm{dddd}, J$ 9.8,

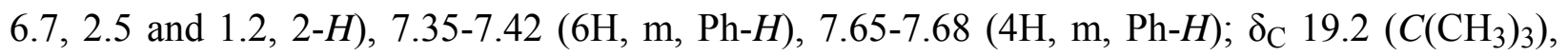

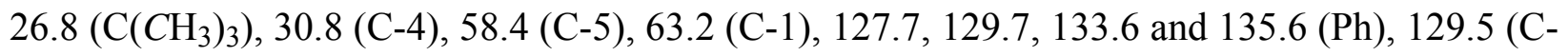
3), 130.9 (C-2); $v_{\max } / \mathrm{cm}^{-1}$ 3300-3500 (s, br., OH), 3071 (m, Ph-H), 3045 (m, C=C-H str.), 2961 and 2930 (s, sat. C-H str.), 1110 (s, C-O str.); m/z (CI, NH 4$) 358$ (43\%, [M+NH$\left.]^{+}\right), 341$ (17, $\mathrm{M}+\mathrm{H}^{+}$). (Found: $(\mathrm{CI})[\mathrm{M}+\mathrm{H}]^{+}=341.1940, \mathrm{C}_{21} \mathrm{H}_{28} \mathrm{O}_{2} \mathrm{Si}$ requires $[\mathrm{M}+\mathrm{H}]^{+} 341.1938$ ).

(2R,3S)-5-(tert-Butyldiphenylsilyloxy)-2,3-epoxypentanol (9). To a dry flask containing $4 \AA$ powdered molecular sieves $(2.5 \mathrm{~g})$, dry dichloromethane $(100 \mathrm{ml})$ and $\mathrm{D}-(-)-$ diethyl tartrate 
$(1.35 \mathrm{ml}, 1.61 \mathrm{~g}, 7.81 \mathrm{mmol})$ at $-22^{\circ} \mathrm{C}$, was added $\mathrm{Ti}\left(\mathrm{O}^{\mathrm{i} P r}\right)_{4}(1.95 \mathrm{ml}, 1.84 \mathrm{~g}, 6.49 \mathrm{mmol})$. A solution of tert-butyl hydroperoxide $(2.6 \mathrm{ml}$ of $5.0 \mathrm{M}$ solution in nonane, $13.0 \mathrm{mmol})$, previously dried over $4 \AA$ powdered molecular sieves for 5 minutes was then added dropwise over a 10 minute period and the suspension stirred at $-20{ }^{\circ} \mathrm{C}$ for 30 minutes. A solution of the (Z)monosilyloxy alcohol $8(2.21 \mathrm{~g}, 6.49 \mathrm{mmol})$ in the minimum amount of dry dichloromethane, was dried over powdered molecular sieves $(4 \AA)$ for 10 minutes and then added to the mixture over a 15 minute period whilst maintaining the temperature between $-20{ }^{\circ} \mathrm{C}$ and $0{ }^{\circ} \mathrm{C}$. The mixture was stirred at $-10{ }^{\circ} \mathrm{C}$ to $0{ }^{\circ} \mathrm{C}$ for 6 hours and then stored overnight at $-22{ }^{\circ} \mathrm{C}$. Water $(40 \mathrm{ml})$ was then added and the mixture stirred for $1 \mathrm{hr}$ whilst warming to room temperature. $30 \%$ Aqueous $\mathrm{NaOH}$ saturated with $\mathrm{NaCl}(9 \mathrm{ml})$ was added and vigorous stirring continued for a further $1 \mathrm{hr}$. The organic phase was separated and the aqueous phase extracted with dichloromethane $(2 \times 50 \mathrm{ml})$. The combined organic layers were dried, filtered and evaporated under reduced pressure. Flash chromatography (40\% EtOAc in hexane) gave the starting alcohol $8(49 \mathrm{mg})$ and the epoxide $9(2.03 \mathrm{~g}, 88 \%)$ as colourless oils. $\mathrm{R}_{\mathrm{f}}\left(40 \%\right.$ EtOAc in hexane) $0.32, \delta_{\mathrm{H}}$ $1.06\left(9 \mathrm{H}, \mathrm{s}, \mathrm{C}\left(\mathrm{CH}_{3}\right)_{3}\right), 1.77-1.92\left(2 \mathrm{H}, \mathrm{m}, 4-\mathrm{H}_{2}\right), 2.29(1 \mathrm{H}, \mathrm{br} . \mathrm{s}, \mathrm{OH}), 3.14-3.23(2 \mathrm{H}, \mathrm{m}, 2-\mathrm{H}$ and 3-H), $3.72\left(2 \mathrm{H}\right.$, br.d, $J$ 5.1, 1- $\left.\mathrm{H}_{2}\right), 3.79\left(2 \mathrm{H}\right.$, td, $J 9.5$ and 4.6, 5- $\left.\mathrm{H}_{2}\right), 7.37-7.44(6 \mathrm{H}, \mathrm{m}, \mathrm{Ph}-\mathrm{H})$,

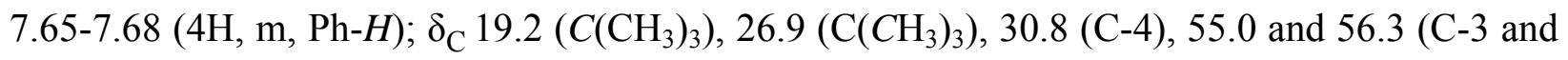
C-2), 60.9 (C-5), 61.4 (C-1), 127.8, 129.9, 133.2 and $135.6(\mathrm{Ph}) ; v_{\max } / \mathrm{cm}^{-1} 3300-3525$ (m, br., OH), 3071 (m, Ph-H str.), 2958 and 2931 (s, sat. C-H str.), 1111 (s, C-O str.), 823 (m, CH-O-CH, epoxide); $\mathrm{m} / \mathrm{z}$ (FAB) $357\left(60 \%, \mathrm{MH}^{+}\right), 269 \quad\left(100, \mathrm{HOCH}_{2} \mathrm{CHOCHCH}_{2}^{+}\right), 235$ (46, $\mathrm{C}\left(\mathrm{CH}_{3}\right)_{3} \mathrm{SiPhOCH}_{2} \mathrm{CH}_{2} \mathrm{COH}^{+}$); (Found: (CI, NH $\left.\mathrm{NH}_{3}\right)\left[\mathrm{M}+\mathrm{NH}_{4}\right]^{+}=374.2177, \mathrm{C}_{21} \mathrm{H}_{32} \mathrm{NO}_{3} \mathrm{Si}$ requires $\left.\left[\mathrm{M}+\mathrm{NH}_{4}\right]^{+} 374.2151\right) ;[\alpha]_{D}^{00}=+7.0$ (c 4.0 in $\left.\mathrm{CHCl}_{3}\right) ; 77 \%$ e.e. determined by conversion to Mosher's ester derivative

(2R,3S)-5-(tert-Butyldiphenylsilyloxy)-2,3-epoxypentanal (10). Solid TPAP (35.1 mg, $0.10 \mathrm{mmol})$ was added in one portion to a stirred mixture of the epoxyalcohol $9(1.43 \mathrm{~g}$, $4.00 \mathrm{mmol})$, 4-methylmorpholine- $N$-oxide $(0.70 \mathrm{~g}, 6.00 \mathrm{mmol})$ and powdered $4 \AA$ molecular sieves $(2.20 \mathrm{~g})$, in dry dichloromethane $(12 \mathrm{ml})$ at room temperature. After stirring for $45 \mathrm{mins}$, the mixture was applied to a 6 inch column of silica and the product eluted with dichloromethane. The solvent was removed under reduced pressure to yield the epoxyaldehyde $\mathbf{1 0}(1.13 \mathrm{~g}, 80 \%)$ as a colourless oil, which was used in the next step without further purification. $\mathrm{R}_{\mathrm{f}}(50 \%$ EtOAc in hexane) $0.38, \delta_{\mathrm{H}} 1.05\left(9 \mathrm{H}, \mathrm{s}, \mathrm{C}\left(\mathrm{CH}_{3}\right)_{3}\right), 1.85-1.98\left(2 \mathrm{H}, \mathrm{m}, 4-\mathrm{H}_{2}\right), 3.38(1 \mathrm{H}, \mathrm{t}, \mathrm{J} 4.9,2-\mathrm{H}), 3.46$ $(1 \mathrm{H}, \mathrm{td}, J 6.3$ and $4.9,3-H), 3.82\left(2 \mathrm{H}, \mathrm{dt}, J 11.2\right.$ and 5.0, 5- $\left.\mathrm{H}_{2}\right), 7.36-7.44(6 \mathrm{H}, \mathrm{m}, \mathrm{Ph}-\mathrm{H}), 7.63-$

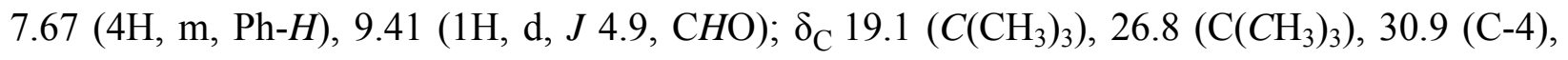
56.9 (C-3), 57.6 (C-2), 60.8 (C-5), 127.7, 129.8, 133.2 and $135.5(\mathrm{Ph}), 198.5(\mathrm{CHO}) ; v_{\max } / \mathrm{cm}^{-1}$ 3071 (m, Ph-H str.), 2958 and 2931 (s, sat. C-H str.), 1725 (s, CHO), 1111 (s, C-O str.), 823 (m, CH-O-CH, epoxide); m/z (FAB) $355\left(5 \%, \mathrm{M}+\mathrm{H}^{+}\right), 267$ (36, $\left.\mathrm{OHCCHOCHCH}_{2} \mathrm{CH}_{2}{ }^{+}\right), 199$ (70, $\mathrm{MH}^{+}-(2 \mathrm{xPh})$ ); Found (FAB) $[\mathrm{MH}]^{+}=355.1750, \mathrm{C}_{21} \mathrm{H}_{27} \mathrm{O}_{3}$ Si requires $[\mathrm{MH}]^{+}=355.1729$.

(2S,3R)-5-(tert-Butyldiphenylsilyloxy)-2-hydroxy-3-methoxypentanal dimethylacetal (11). Amberlyst-15 $(136 \mathrm{mg})$ was added portion wise to a stirring solution of the epoxy aldehyde 10 $(746.3 \mathrm{mg}, 2.09 \mathrm{mmol})$ in trimethyl orthoformate $(1.4 \mathrm{ml}, 1.36 \mathrm{~g}, 12.8 \mathrm{~mol})$ at $0{ }^{\circ} \mathrm{C}$ to $4{ }^{\circ} \mathrm{C}$. The 
mixture was stirred at this temperature for $6 \mathrm{hrs}$, then filtered to remove the Amberlyst- 15 . Excess trimethyl orthoformate was removed under reduced pressure and the residue purified by flash chromatography (first treating with a solution of $1 \% \mathrm{Et}_{3} \mathrm{~N}$ in methanol, then washed with $20 \%$ EtOAc in hexane and eluting with $20 \%$ EtOAc in hexane) to give the ether acetal $\mathbf{1 1}$ (720 mg, 86\%) as a colourless oil. $\mathrm{R}_{\mathrm{f}}\left(70 \%\right.$ EtOAc in hexane) $0.42, \delta_{\mathrm{H}} 1.05\left(9 \mathrm{H}, \mathrm{s}, \mathrm{C}\left(\mathrm{CH}_{3}\right)_{3}\right)$, 1.83-1.89 (2H, m, 4- $\left.\mathrm{H}_{2}\right), 2.41(1 \mathrm{H}, \mathrm{br} . \mathrm{s}, \mathrm{OH}), 3.39\left(3 \mathrm{H}, \mathrm{s}, \mathrm{OCH}_{3}\right), 3.43\left(3 \mathrm{H}, \mathrm{s}, \mathrm{OCH}_{3}\right), 3.44(3 \mathrm{H}$, s, $\left.\mathrm{OCH}_{3}\right), 3.56(1 \mathrm{H}$, br.d, $J 6.5,2-H), 3.66(1 \mathrm{H}, \mathrm{td}, J 6.5$ and $2.2,3-H), 3.77(2 \mathrm{H}, \mathrm{dt}, J 12.1$ and 6.0, 5- $\left.\mathrm{H}_{2}\right), 4.44(1 \mathrm{H}, \mathrm{d}, J$ 6.5, 1-H), 7.35-7.45 (6H, m, Ph- $H), 7.65-7.68(4 \mathrm{H}, \mathrm{m}, \mathrm{Ph}-\mathrm{H}) ; \delta_{\mathrm{C}} 19.2$

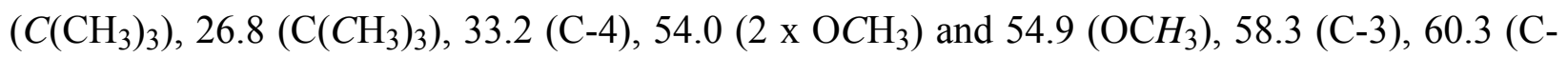
5), 72.3 (C-2), $104.2(\mathrm{C}-1), 127.7,129.6,133.6$ and $135.6(\mathrm{Ph}) ; v_{\max } / \mathrm{cm}^{-1} 3300-3500$ (m, br., OH), 3071 (m, Ph-H str.), 2961 and 2931 (s, sat. C-H str.), 1111 (s, C-O str.), 823 (m, CH-O-CH epoxide); $\mathrm{m} / \mathrm{z}$ (FAB) $455\left(100 \%, \mathrm{M}+\mathrm{Na}^{+}\right) ;[\alpha]_{D}^{0}=+11.1$ (c 4.5 in $\left.\mathrm{CHCl}_{3}\right)$.

(E)-5-(tert-Butyldiphenylsilyloxy)pent-2-en-ol (12). To a solution of 5-(tertbutyldiphenylsilyloxy)-2-pentyn-1-ol $7(10.16 \mathrm{~g}, 30.0 \mathrm{mmol})$ in dry THF $(100 \mathrm{ml})$ was added dropwise, lithium aluminium hydride ( $33 \mathrm{ml}, 33.0 \mathrm{mmol} ; 1.0 \mathrm{M}$ soln in THF) and the reaction mixture stirred at RT for 5 mins. The reaction mixture was then stirred at $45{ }^{\circ} \mathrm{C}$ for 30 mins, allowed to cool to room temperature and then cooled $\left(0{ }^{\circ} \mathrm{C}\right)$. The reaction mixture was hydrolysed by the slow addition of sufficient saturated aqueous ammonium chloride solution, then a further $75 \mathrm{ml}$ of saturated aqueous ammonium chloride solution was added. The product was extracted with ether $(3 \times 100 \mathrm{ml})$, the combined ethereal extracts dried, filtered and concentrated under reduced pressure. The residue was purified by flash chromatography $(40 \%$ EtOAc in hexane) to give the trans-allylic alcohol 12 as a colourless oil $(7.76 \mathrm{~g}, 76 \%) . \mathrm{R}_{\mathrm{f}}(50 \%$ EtOAc in hexane) $0.38, \delta_{\mathrm{H}} 1.04\left(9 \mathrm{H}, \mathrm{s}, \mathrm{C}\left(\mathrm{CH}_{3}\right)_{3}\right), 1.41(1 \mathrm{H}$, br. t, $J 4.9, \mathrm{OH}), 2.27-2.32(2 \mathrm{H}, \mathrm{m}$, 4- $\left.\mathrm{H}_{2}\right), 3.70\left(2 \mathrm{H}, \mathrm{t}, J 6.6,5-\mathrm{H}_{2}\right), 4.03-4.05\left(2 \mathrm{H}, \mathrm{m}, 1-\mathrm{H}_{2}\right), 5.64-5.67(2 \mathrm{H}, \mathrm{m}, 2-\mathrm{H}$ and $3-\mathrm{H}), 7.34-$

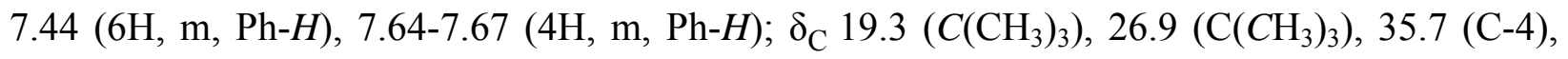
63.6 and $63.8(\mathrm{C}-1$ and $\mathrm{C}-5), 127.7,129.6,129.7$ and $135.7(\mathrm{Ph}), 131.0(\mathrm{C}-3), 134.0(\mathrm{C}-2)$; $v_{\max } / \mathrm{cm}^{-1}$ 3200-3400 (s, br., OH), 3071 (m, Ph-H), 3049 (m, C=C-H str.), 2960-2930 (s, sat. C-H str.), 1111 (s, C-O str.); m/z (FAB) $364\left(29 \%,[\mathrm{M}+\mathrm{H}+\mathrm{Na}]^{+}\right), 363\left(90, \mathrm{M}+\mathrm{Na}^{+}\right)$; (Found: (FAB) $[\mathrm{M}+\mathrm{Na}]^{+}=363.1748, \mathrm{C}_{21} \mathrm{H}_{28} \mathrm{O}_{2} \mathrm{Si}$ requires $\left.[\mathrm{M}+\mathrm{Na}]^{+} 363.1756\right)$.

(2R,3R)-5-(tert-Butyldiphenylsilyloxy)-2,3-epoxypentanol (13). To a dry flask containing $4 \AA$ powdered molecular sieves $(2.0 \mathrm{~g})$, dry dichloromethane $(150 \mathrm{ml})$ and $\mathrm{D}-(-)-$ diethyl tartrate $(2.0 \mathrm{ml}, 2.41 \mathrm{~g}, 11.7 \mathrm{mmol})$ at $-22{ }^{\circ} \mathrm{C}$, was added $\mathrm{Ti}(\mathrm{O} \text { Pr })_{4}(2.90 \mathrm{ml}, 2.76 \mathrm{~g}, 9.72 \mathrm{mmol})$. A solution of tert-butyl hydroperoxide $(3.55 \mathrm{ml}$ of $5.5 \mathrm{M}$ solution in nonane, $19.5 \mathrm{mmol})$, previously dried over $4 \AA$ powdered molecular sieves for 5 minutes was then added dropwise over a 10 minute period and the suspension stirred at $-20{ }^{\circ} \mathrm{C}$ for 30 minutes. A solution of the (E)-monosilyloxy alcohol $12(3.31 \mathrm{~g}, 9.72 \mathrm{mmol})$ in the minimum amount of dry

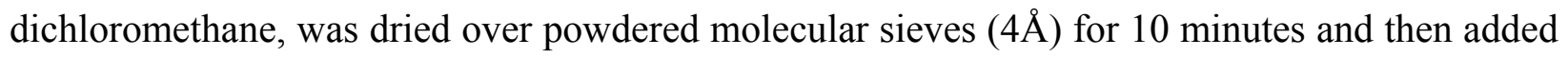
to the mixture over a 15 minute period whilst maintaining the temperature between $-20{ }^{\circ} \mathrm{C}$ and $0{ }^{\circ} \mathrm{C}$. The mixture was stirred at $-10{ }^{\circ} \mathrm{C}$ to $0{ }^{\circ} \mathrm{C}$ for 6 hours and then stored overnight at $-22{ }^{\circ} \mathrm{C}$. Water $(61 \mathrm{ml})$ was then added and the mixture stirred for $1 \mathrm{hr}$ whilst warming to room 
temperature. $30 \%$ Aqueous $\mathrm{NaOH}$ saturated with $\mathrm{NaCl}(13 \mathrm{ml})$ was added and vigorous stirring continued for a further $1 \mathrm{hr}$. The organic phase was separated and the aqueous phase extracted with dichloromethane $(2 \times 75 \mathrm{ml})$. The combined organic layers were dried, filtered and evaporated under reduced pressure. Flash chromatography (40\% EtOAc in hexane) gave the starting alcohol 12 (43.5 mg) and the epoxide $13(2.99 \mathrm{~g}, 86 \%)$ as colourless oils. $\mathrm{R}_{\mathrm{f}}(50 \%$ EtOAc in hexane) $0.25, \delta_{\mathrm{H}} 1.05\left(9 \mathrm{H}, \mathrm{s}, \mathrm{SiC}\left(\mathrm{CH}_{3}\right)_{3}\right), 1.79\left(2 \mathrm{H}, \mathrm{dd}, J 11.9\right.$ and 6.0, 4- $\left.\mathrm{H}_{2}\right), 2.03$ $(1 \mathrm{H}, \mathrm{t}, J 6.0, \mathrm{OH}), 2.97(1 \mathrm{H}, \mathrm{td}, J 4.7$ and $2.3,2-H), 3.12(1 \mathrm{H}, \mathrm{td}, J 5.8$ and $2.3,3-H), 3.58(1 \mathrm{H}$, $\mathrm{dd}, J 12.6$ and $\left.4.7,1-\mathrm{H}_{\mathrm{A}} H_{\mathrm{B}}\right), 3.78-3.82\left(2 \mathrm{H}, \mathrm{m}, 5-H_{2}\right), 3.89\left(1 \mathrm{H}, \mathrm{dd}, J 12.6\right.$ and $\left.2.4,1-H_{\mathrm{A}} \mathrm{H}_{\mathrm{B}}\right)$,

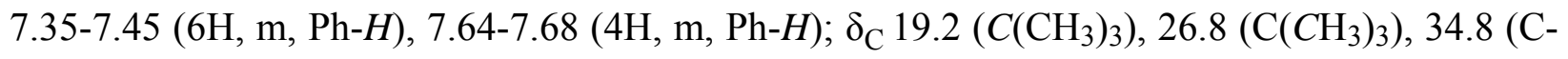
4), 53.7 (C-3), 58.7 (C-2), 60.7 (C-5), 61.7 (C-1), 127.7, 129.7, 133.5 and $135.5(\mathrm{Ph}) ; v_{\max } / \mathrm{cm}^{-1}$ 3300-3400 (m, br., OH), 3071 (m, Ph-H str.), 2961 and 2931 (s, sat. C-H str.), 1112 (s, C-O str.), 823 (m, CH-O-CH, epoxide), m/z (FAB) 379 (100\%, M+Na ${ }^{+}$, 279 (66, M-Ph); (Found: (FAB) $[\mathrm{M}+\mathrm{Na}]^{+}=379.1713, \mathrm{C}_{21} \mathrm{H}_{28} \mathrm{O}_{3} \mathrm{Si}$ requires $\left.[\mathrm{M}+\mathrm{Na}]^{+} 379.1705\right) ;[\alpha]_{\mathrm{D}}^{20}=+22.5\left(\right.$ c 4.0 in $\left.\mathrm{CHCl}_{3}\right)$, $95 \%$ e.e. determined by conversion to Mosher's ester derivative.

(2S,3R)-5-(tert-Butyldiphenylsilyloxy)-2,3-epoxypentanal (14). Solid TPAP (104.4 mg, $0.30 \mathrm{mmol}$ ) was added in one portion to a stirred mixture of the epoxy alcohol 13 (2.32 $\mathrm{g}$, $6.50 \mathrm{mmol})$, 4-methylmorpholine- $N$-oxide $(1.15 \mathrm{~g}, 9.80 \mathrm{mmol})$ and powdered $4 \AA$ molecular sieves $(3.50 \mathrm{~g})$, in dry dichloromethane $(20 \mathrm{ml})$ at room temperature. After stirring for $45 \mathrm{mins}$, the mixture was applied to a 6 inch column of silica and the product eluted with dichloromethane. The solvent was removed under reduced pressure to yield the epoxy aldehyde 14 (1.84 g, 80\%) as a colourless oil, which was used in the next step without further purification. $\mathrm{R}_{\mathrm{f}}(50 \%$ EtOAc in hexane) $0.49, \delta_{\mathrm{H}} 1.06\left(9 \mathrm{H}, \mathrm{s}, \mathrm{C}\left(\mathrm{CH}_{3}\right)_{3}\right), 1.81-1.90\left(2 \mathrm{H}, \mathrm{m}, 4-\mathrm{H}_{2}\right), 3.19(1 \mathrm{H}, \mathrm{dd}, \mathrm{J} 6.4$ and 2.0, 2-H), $3.41\left(1 \mathrm{H}, \mathrm{td}, J 5.6\right.$ and 2.0, 3-CH), 3.77-3.85 (2H, m, 5- $\left.\mathrm{H}_{2}\right), 7.36-7.44(6 \mathrm{H}, \mathrm{m}, \mathrm{Ph}-\mathrm{H})$,

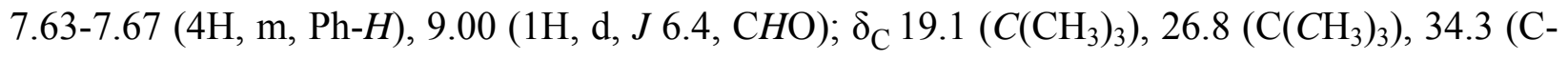
4), 54.7 (C-3), 59.1 (C-2), 60.4 (C-5), 127.8, 129.8, 133.3 and $135.5(\mathrm{Ph}), 198.2$ (CHO); $v_{\max } / \mathrm{cm}^{-1} 3072$ (m, Ph-H str.), 2961 and 2931 (s, sat. C-H str.), 1731 (s, CHO), 111 (s, C-O str.), 823 (m, CH-O-CH, epoxide); m/z (CI, NH $\mathrm{N}_{4} 355$ (8\%, $\left.\mathrm{MH}^{+}\right), 277$ (10, $\left.\mathrm{M}^{+}-\mathrm{Ph}\right), 267$ (100, $\left.\mathrm{OHCCHOCHCH}_{2} \mathrm{CH}_{2}^{+}\right), 199\left(10, \mathrm{MH}^{+}-(2 \mathrm{xPh})\right.$ ); Found $\left(\mathrm{CI}, \mathrm{NH}_{4}\right)[\mathrm{M}+\mathrm{H}]^{+}=355.1704$, $\mathrm{C}_{21} \mathrm{H}_{26} \mathrm{O}_{3} \mathrm{Si}$ requires $[\mathrm{M}+\mathrm{H}]^{+}=355.1729$.

(2S,3R)-5-(tert-Butyldiphenylsilyloxy)-2,3-epoxypentanal dimethylacetal (15). Amberlyst-15 $(258 \mathrm{mg})$ was added portion wise to a stirring solution of the epoxy aldehyde 14 (1.55 g, $4.37 \mathrm{mmol})$ in trimethyl orthoformate $(2.95 \mathrm{ml}, 2.85 \mathrm{~g}, 26.9 \mathrm{~mol})$ at $0{ }^{\circ} \mathrm{C}$ to $4{ }^{\circ} \mathrm{C}$. The mixture was stirred at this temperature for $6 \mathrm{hrs}$, then filtered to remove the Amberlyst-15. Excess trimethyl orthoformate was removed under reduced pressure and the residue purified by flash chromatography (first treating with a solution of $1 \% \mathrm{Et}_{3} \mathrm{~N}$ in methanol, then washed with $20 \%$ EtOAc in hexane and eluting with 20\% EtOAc in hexane) to give the epoxy acetal 15 (1.49 g, $85 \%)$ as a colourless oil. $\mathrm{R}_{\mathrm{f}}\left(50 \%\right.$ EtOAc in hexane) $0.41, \delta_{\mathrm{H}} 1.06\left(9 \mathrm{H}, \mathrm{s}, \mathrm{C}\left(\mathrm{CH}_{3}\right)_{3}\right), 1.72-1.90$ $\left(2 \mathrm{H}, \mathrm{m}, 4-\mathrm{H}_{2}\right), 2.92(1 \mathrm{H}, \mathrm{dd}, J 4.2$ and 1.6, 2-H), $3.17(1 \mathrm{H}, \mathrm{td}, J 6.2$ and 1.6, 3- $\mathrm{H}), 3.41(3 \mathrm{H}, \mathrm{s}$, $\left.\mathrm{OCH}_{3}\right), 3.42\left(3 \mathrm{H}, \mathrm{s}, \mathrm{OCH}_{3}\right), 3.76-3.84\left(2 \mathrm{H}, \mathrm{m}, 5-\mathrm{H}_{2}\right), 4.27(1 \mathrm{H}, \mathrm{d}, \mathrm{J} 4.2,1-\mathrm{H}), 7.36-7.45(6 \mathrm{H}, \mathrm{m}$,

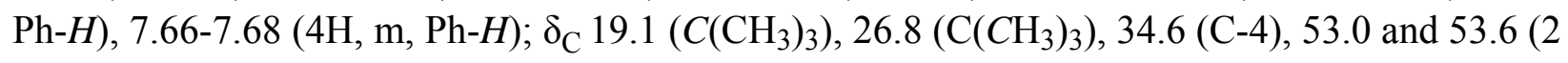


x $\left.\mathrm{OCH}_{3}\right), 54.3(\mathrm{C}-3), 57.3(\mathrm{C}-2), 60.7(\mathrm{C}-5), 102.7(\mathrm{C}-1), 127.6,129.6,133.6$ and $135.6(\mathrm{Ph})$; $v_{\max } / \mathrm{cm}^{-1} 3071$ (m, Ph-H str.), 2961 and 2931 (s, sat. C-H str.), 1111 (s, C-O str.), 823 (m, CHO-CH epoxide); $\mathrm{m} / \mathrm{z}(\mathrm{FAB}) 423\left(13 \%, \mathrm{MNa}^{+}\right), 401\left(5, \mathrm{MH}^{+}\right)$; (Found: $(\mathrm{FAB})[\mathrm{M}+\mathrm{Na}]^{+}=$ 423.1968, $\mathrm{C}_{23} \mathrm{H}_{32} \mathrm{O}_{4} \mathrm{Si}$ requires $\left.[\mathrm{M}+\mathrm{Na}]^{+} 423.1978\right) ;[\alpha]_{D}^{0}=+16.3$ (c 4.3 in $\mathrm{CHCl}_{3}$ ).

(2S,3S)-3-Azido-5-(tert-butyldiphenylsilyloxy)-2-hydroxypentanal dimethylacetal (16). Sodium azide $(1.12 \mathrm{~g}, 17.2 \mathrm{mmol})$ and ammonium chloride $(0.40 \mathrm{~g}, 7.57 \mathrm{mmol})$ were added to a stirring solution of the epoxy acetal 15 (1.38 g, $3.44 \mathrm{mmol})$ in $\mathrm{MeOH}: \mathrm{H}_{2} \mathrm{O} ; 8: 1$ (30 ml) and the reaction heated under reflux for $48 \mathrm{hrs}$. The mixture was allowed to cool to room temperature, then diluted with water $(30 \mathrm{ml})$ and extracted with ether $(3 \times 50 \mathrm{ml})$. The organic phases were combined, dried, filtered and evaporated under reduced pressure. The residue was chromatographed (first treating with a solution of $1 \% \mathrm{Et}_{3} \mathrm{~N}$ in methanol, then washed with $20 \%$ EtOAc in hexane, eluting with 20\% EtOAc in hexane), to give the starting epoxy acetal 15 $(87 \mathrm{mg})$ and the azido alcohol $16(1.13 \mathrm{~g}, 74 \%)$ as colourless oils. $\mathrm{R}_{\mathrm{f}}(50 \%$ EtOAc in hexane) $0.28, \delta_{\mathrm{H}} 1.06\left(9 \mathrm{H}, \mathrm{s}, \mathrm{C}\left(\mathrm{CH}_{3}\right)_{3}\right), 1.69-1.78\left(1 \mathrm{H}, \mathrm{m}, 4-\mathrm{H}_{\mathrm{A}} H_{\mathrm{B}}\right), 1.86-1.95\left(1 \mathrm{H}, \mathrm{m}, 4-\mathrm{H}_{\mathrm{A}} \mathrm{H}_{\mathrm{B}}\right), 2.52$ $(1 \mathrm{H}, \mathrm{d}, J 3.1, \mathrm{OH}), 3.42\left(3 \mathrm{H}, \mathrm{s}, \mathrm{OCH}_{3}\right), 3.48\left(3 \mathrm{H}, \mathrm{s}, \mathrm{OCH}_{3}\right), 3.74-3.77(1 \mathrm{H}, \mathrm{m}, 2-\mathrm{H}), 3.80(2 \mathrm{H}, \mathrm{td}$, $J 10.6$ and 8.4, 5- $\left.H_{2}\right), 3.86(1 \mathrm{H}$, ddd, $J 10.0,7.9$ and 4.5, 3-H), $4.36(1 \mathrm{H}, \mathrm{d}, J$ 5.7, 1-H), 7.36-7.45

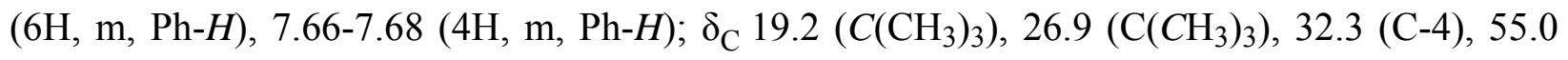
and $55.4\left(2 \times \mathrm{OCH}_{3}\right), 60.2(\mathrm{C}-3), 60.3(\mathrm{C}-5), 73.4(\mathrm{C}-2), 103.9(\mathrm{C}-1), 127.8,129.8,133.4,133.5$ and $135.6(\mathrm{Ph}) ; v_{\max } / \mathrm{cm}^{-1} 3350-3525$ (m, br., OH), 3071 (m, Ph-H str.), 2961 and 2931 (s, sat. C-

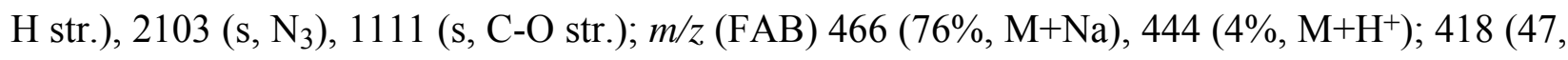
$\mathrm{M}-\left(\mathrm{N}_{2}+3 \mathrm{H}\right)$ ); (Found: $(\mathrm{FAB})[\mathrm{M}+\mathrm{Na}]^{+}=466.2120, \mathrm{C}_{23} \mathrm{H}_{33} \mathrm{~N}_{3} \mathrm{O}_{4}$ Si requires $\left.[\mathrm{M}+\mathrm{Na}]^{+} 466.2138\right)$; $[\alpha]_{D}^{20}=-20.0$ (c 6.0 in $\mathrm{CHCl}_{3}$ ).

(2S,3S)-2-Acetoxy-5-(tert-butyldiphenylsilyloxy)-3-azidopentanal dimethylacetal (17). The azido acetal 16 (44.4 $\mathrm{mg}, 0.10 \mathrm{mmol})$ was stirred with excess pyridine: acetic anhydride; 2:1 $(6 \mathrm{ml})$ at RT overnight. The solution was then concentrated in vacuo, flash chromatography (20\% EtOAc in hexane) gave the azido acetate $17(46.1 \mathrm{mg}, 95 \%)$ as a colourless oil. $\mathrm{R}_{\mathrm{f}}(20 \%$ EtOAc in hexane) $0.38, \delta_{\mathrm{H}} 1.06\left(9 \mathrm{H}, \mathrm{s}, \mathrm{C}\left(\mathrm{CH}_{3}\right)_{3}\right), 1.63-1.71\left(1 \mathrm{H}, \mathrm{m}, 4-\mathrm{H}_{\mathrm{A}} \mathrm{H}_{\mathrm{B}}\right), 1.80-1.89(1 \mathrm{H}, \mathrm{m}$, $\left.4-H_{\mathrm{A}} \mathrm{H}_{\mathrm{B}}\right), 2.11\left(3 \mathrm{H}, \mathrm{s}, \mathrm{COCH}_{3}\right), 3.38\left(3 \mathrm{H}, \mathrm{s}, \mathrm{OCH}_{3}\right), 3.39\left(3 \mathrm{H}, \mathrm{s}, \mathrm{OCH}_{3}\right), 3.74-3.83(2 \mathrm{H}, \mathrm{m}, 5-$ $\left.H_{2}\right), 3.94(1 \mathrm{H}, \mathrm{ddd}, J 10.0,8.0,4.2,3-H), 4.43(1 \mathrm{H}, \mathrm{d}, J 6.2,1-H), 5.19(1 \mathrm{H}, \mathrm{dd}, J 6.2$ and 4.2, 2-

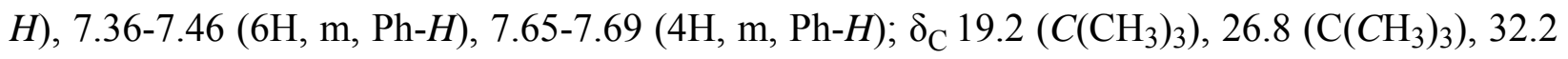
(C-4), 53.6 and $55.3\left(2 \times \mathrm{OCH}_{3}\right), 58.8(\mathrm{C}-3), 60.0$ (C-5), 72.5 (C-2), 102.2 (C-1), 127.7, 129.7, 133.5, and $135.5(\mathrm{Ph}), 169.8(\mathrm{C}=\mathrm{O}) ; v_{\max } / \mathrm{cm}^{-1} 3072(\mathrm{~m}, \mathrm{Ph}-\mathrm{H}$ str.), 2962 and 2932 (s, sat. C-H str.), 2108 (s, N3), 1753 (s, C=O), 1111 (s, C-O str.); m/z (FAB) 509 (34\%, [M+H+Na] $\left.]^{+}\right), 508$ $\left(100, \mathrm{MNa}^{+}\right)$; (Found: $(\mathrm{FAB})[\mathrm{M}+\mathrm{Na}]^{+}=508.2207, \mathrm{C}_{25} \mathrm{H}_{35} \mathrm{~N}_{3} \mathrm{O}_{5}$ Si requires $[\mathrm{M}+\mathrm{Na}]^{+}$508.2244); $[\alpha]_{D}^{20}=-19.3$ (c 4.3 in $\mathrm{CHCl}_{3}$ ).

(3S,4S)-4-Azidotetrahydropyran-2,3-diol (4). To a solution of (2S,3S)-3-azido-5-(tert-butyldiphenylsilyloxy)-2-hydroxypentanal dimethylacetal $16(732 \mathrm{mg}, 1.65 \mathrm{mmol})$ in chloroform $(6 \mathrm{ml})$ and water $(120 \mu \mathrm{l})$ at $0{ }^{\circ} \mathrm{C}$ was added trifluoroacetic acid $(6 \mathrm{ml})$ dropwise. The mixture was stirred at $0{ }^{\circ} \mathrm{C}$ for $3 \mathrm{hrs}$ and then concentrated under reduced pressure. The residue was 
dissolved in THF $(5 \mathrm{ml})$ and tetrabutylammonium fluoride $(4.36 \mathrm{~g}, 2.50 \mathrm{mmol}, 15 \mathrm{wt} \%$ on alumina) was added and the reaction mixture stirred at RT overnight. The mixture was concentrated under reduced pressure and the residue purified by flash chromatography on silica gel (first treated with $1 \% \mathrm{Et}_{3} \mathrm{~N}$ in methanol, then washed with $50 \%$ EtOAc in hexane, eluting with $60 \%$ EtOAc in hexane to $80 \%$ EtOAc in hexane) to yield the unstable hemiacetal 385 (144 mg, 55\%) as a colourless oil, which was used immediately in the next reaction. $\mathrm{R}_{\mathrm{f}}(80 \%$ EtOAc in hexane) 0.30, $\delta_{\mathrm{C}} 25.2$ and 27.5 (C-5, two anomers), 58.2 and 59.3 (C-4, two anomers), 59.6 and 60.5 (C-6, two anomers), 69.2 and 70.9 (C-3, two anomers), 94.4 and 94.5 (C-2, two anomers); $v_{\max } / \mathrm{cm}^{-1} 3200-3500$ (s, br., OH), 2930 (m, sat. C-H str.), 2102 (s, N3), 1066 (m, C-O str.). The ${ }^{1} \mathrm{H}$ nmr was too complex to assign apart from the anomeric protons mentioned in the discussion.

(2S,3S,4S)-4-Azido-3-hydroxy-2-methoxytetrahydropyran and (2R,3S,4S)-4-Azido-3-hydroxy2-methoxytetrahydropyran (18). Trimethyl orthoformate $(0.4 \mathrm{ml}, 3.60 \mathrm{mmol})$ was added to a solution of the hemiacetal $4(16 \mathrm{mg}, 0.10 \mathrm{mmol})$ in methanol $(1.5 \mathrm{ml})$. p-Toluenesulphonic acid ( 1 crystal) was added and the reaction stirred at RT for 7 days. Dichloromethane $(10 \mathrm{ml})$ and saturated aqueous sodium hydrogen carbonate solution $(5 \mathrm{ml})$ was added, the organic layer removed, then the aqueous layer extracted with dichloromethane $(3 \times 10 \mathrm{ml})$. The combined organic extracts were dried, filtered, and concentrated under reduced pressure. Flash chromatography (60\% EtOAc in hexane) gave the methyl acetal $18(12.1 \mathrm{mg}, 70 \%)$ as a mixture of anomers in a ratio of 2.8:1. $\delta_{\mathrm{H}} 1.76\left(1 \mathrm{H}\right.$, ddd, $J 12.8,8.1$ and $4.2,5-\mathrm{H}_{\mathrm{A}} H_{\mathrm{B}}$ (major)), 1.82-1.90 $\left(1 \mathrm{H}, \mathrm{m}, 5-\mathrm{H}_{\mathrm{A}} \mathrm{H}_{\mathrm{B}}\right.$ (minor)), 1.96-2.06 $\left(2 \mathrm{H}, \mathrm{m}, 5-\mathrm{H}_{\mathrm{A}} \mathrm{H}_{\mathrm{B}}\right.$ (major + minor)), $2.18(1 \mathrm{H}$, br. s, $\mathrm{OH}$ (major)), 2.47 (1H, br. s, OH (minor)), 3.42 (3H, s, $\mathrm{OCH}_{3}$ (major)), 3.49 (3H, s, $\mathrm{OCH}_{3}$ (minor)), $3.69\left(1 \mathrm{H}, \mathrm{ddd}, J 12.8,8.0\right.$ and $3.9,6-\mathrm{H}_{\mathrm{A}} H_{\mathrm{B}}$ (minor)), 3.73-3.78 $\left(3 \mathrm{H}, \mathrm{m}, 6-\mathrm{H}_{2}\right.$ and $4-\mathrm{H}$ (major)), $3.80(1 \mathrm{H}, \mathrm{dd}, J 5.8$ and 3.3, 4- $H$ (minor)), 3.83-3.86 (2H, m, 3- $H$ (major and minor)), $3.95(1 \mathrm{H}$, ddd, $J 12.8,8.0$ and 3.9, 6- $H_{\mathrm{A}} \mathrm{H}_{\mathrm{B}}$ (minor)), 4.46 (1H, d, $J 2.9,2-H$ (minor)), 4.61 (1H, d, $J$ 3.6, 2$H$ (major)); $\delta_{\mathrm{C}} 26.1$ (C-5, two anomers), $55.5\left(\mathrm{OCH}_{3}\right.$, two anomers), 57.3 (C-4, two anomers), 58.6 and 58.9 (C-6, two anomers), 69.4 (C-3, two anomers), 100.8 (C-2, two anomers); $v_{\max } / \mathrm{cm}^{-}$ 1 3300-3500 (s, br., OH), 2954 and 2931 (m, sat. C-H str.), 2096 (s, N3), 1061 (m, C-O str.); m/z (FAB) $196(85 \%, \mathrm{M}+\mathrm{Na}), 174\left(8 \%, \mathrm{M}+\mathrm{H}^{+}\right)$; (Found: (FAB) $[\mathrm{M}+\mathrm{Na}]^{+}=196.1731, \mathrm{C}_{6} \mathrm{H}_{11} \mathrm{~N}_{3} \mathrm{O}_{3}$ requires $\left.[\mathrm{M}+\mathrm{Na}]^{+} 196.1725\right)$;

\section{References}

1. Gijsen, H. J. M.; Qiao, L.; Fitz, W.; Wong, C-H. Chem. Rev. 1996, 96, 443.

2. Holt, K. E.; Leeper, F. J.; Handa, S. J. Chem. Soc. Perkin Trans. I 1994, 231.

3. Bednarski, M. D.; Simon, E. S.; Bischofberger, N.; Fessner, W.-D.; Kim, M.-J.; Lees, W.; Saito, T.; Waldmann, H.; Whitesides, G. M. J. Am. Chem. Soc. 1989, 111, 627.

4. Wipf, P.; Xu, W. Org. Synth. 1996, 74, 205.

5. Argenti, L. ; Bellina, F.; Carpita, A.; Rossi, E.; Rossi, R. Synth. Commun. 1994, 16, 2281. 
6. Takano, S.; Shimazaki, Y.; Sekiguchi, Y.; Ogasawara, K. Synth. Commun. 1989, 11, 539.

7. Görgen, G.; Boland, W. Helv. Chim. Acta 1989, 72, 917.

8. Katzuki, T.; Sharpless, K. B. J. Am. Chem. Soc. 1980, 102, 5976.

9. Sharpless, K. B. In Comprehensive Organic Synthesis; Trost, B. M.; Fleming, I., Eds.; Pergamon: Oxford, 1991, Vol. 7, pp 389.

10. Griffiths, W. P.; Ley, S. V. Aldrichim. Acta 1990, 23, 13. 